\title{
Preliminary Study of Mineral Sand in Samadua District, South Aceh Regency
}

\author{
Bakruddin Bin Dulah Iman ${ }^{\mathrm{a}, 1, *}$, Faukas Rachmatillah ${ }^{\mathrm{b}, 2}$, Asbahrul Amri ${ }^{\mathrm{c}, 3}$ \\ ${ }^{a, b, c}$ Departement of Industrial Engineering, Politeknik Aceh Selatan, Tapaktuan 23711, Indonesia \\ ${ }^{1}$ bakry.klt@gmail.com*; ${ }^{2}$ rachmatillahfaukas@gmail.com,3asbahrul.alr@gmail.com
}

ARTICLE INFO (8 pt)

Article history:

Accepted

Keywords:

Quartz sand

Aceh Selatan

Samadua

XRD

SEM-EDX

\section{ABSTRACT (10PT)}

A study on mineral sand has been carried out in Samadua District, South Aceh Regency. This study aims to determine the mineral phase and the shape of the surface morphology of the mineral sand. The methods used in this research are XRD and SEM-EDX methods. The XRD analysis results obtained that the $\mathrm{SiO} 2$ mineral phase was the highest peak, followed by other mineral phases. While the SEMEDX test results, visually the surface morphology of the sample is clear that it is dominated by white with Si elements as large as 17.62 $\mathrm{wt} \%$, Ca elements as large as $04.30 \mathrm{wt} \%$, and $\mathrm{K}$ elements as rough as $02.42 \mathrm{wt} \%$. Based on these results it can be concluded that the phase The dominant constituent minerals in mineral sand are the element $\mathrm{SiO} 2$ (Silica).

Copyright (C) 2021 Politeknik Aceh Selatan. All rights reserved.

\section{Introduction}

Potential non-metallic natural resources such as quartz can be found in coastal areas, such as in South Aceh District. This area is based on the potential for quartz sand resources reaching 600,000 tons in Samadua District, while in other areas, namely Sawang District, it is 250,000 tons[1]. Quartz sand is widely used in various industrial purposes such as cement, concrete, ceramics, glass, and so on[2]. Quartz minerals can be used as raw material for silicon for the manufacture of solar panels [3]. Various studies have been carried out related to quartz sand, however in this study the area has not been carried out preliminary studies so that it is necessary to conduct a study to determine the potential of the elements contained in the mineral sand. very fameliar used in various studies in determining mineral phases in sand or rock. Then, to determine the surface morphology, it is used Scanning Electron Microscopy Energy Dispersive X-ray Spectroscopy (SEM-EDX). From these two methods, it is hoped that initial information regarding mineral sands in South Aceh will be obtained.

\section{Method}

This research includes several stages of the process, namely taking sand samples, sample preparation processes, and laboratory testing processes, the next stage is to perform data analysis.

\section{A. Location and sampling}

Sand samples were taken in Samadua District, South Aceh Regency, and were taken using PVC pipes with a size of 3 Inch and a length of approximately $50 \mathrm{~cm}$. then the pipe is plugged into the sand with a depth of $\pm 40 \mathrm{~cm}$ and then refilled. The sampling location is shown in Figure 1.

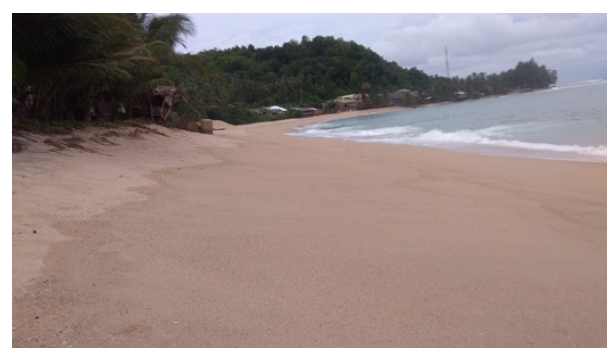

Fig 1. Sampling location 


\section{B. Sample Preparation}

The sample is dried in the sun first, then refinement is carried out in powder size using a pestle and mortar, while the appearance of the sample is ready for testing can be seen as in Figure 2 below.

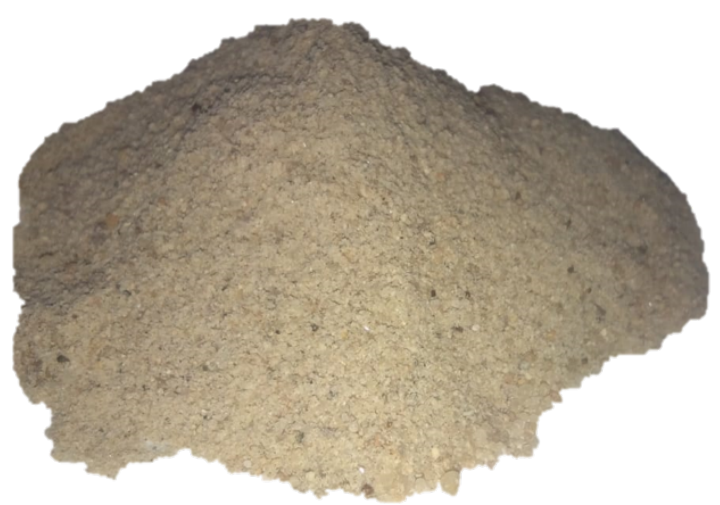

Fig 2. Sample in powder size

\section{Testing}

Sand samples that have been prepared in powder size are then tested in the laboratory using an $\mathrm{X}$-ray Difrractometer (XRD) machine with the Shimadzu X-ray diffraction technique, Co-K $\alpha$ radiation $(\lambda=1.54060 \AA)$ at an angle of $2 \Theta$ [4]. To determine the surface morphology of the sample, it was carried out using Scanning Electron Microscopy Energy Dispersive X-ray Spectroscopy (SEM-EDX)[5].

\section{Results and Discussion}

Based on the results of X-Ray Diffraction and Scanning Electron Microscopy, Energy Dispersive $\mathrm{X}$-ray Spectroscopy on mineral sand samples, Samadua District, South Aceh Regency are as follows.

\section{A. X-Ray Difraction}

The results of the X-Ray Difraction test on mineral sand show that there is a dominant mineral phase with high intensity, namely $100,13.01$ and 11.41 , while the rest is a minor phase as shown in Table 1 below.

Table 1. X-Ray Diffraction of mineral sand sample data

\begin{tabular}{cccc}
\hline No & 2 Theta $\left({ }^{\circ}\right)$ & d $\left(\boldsymbol{A}^{\circ}\right)$ & I \\
\hline 1 & 26.5842 & 3.35313 & 100 \\
2 & 20.8058 & 4.26950 & 13.01 \\
3 & 68.0607 & 1.37644 & 11.41 \\
\hline
\end{tabular}




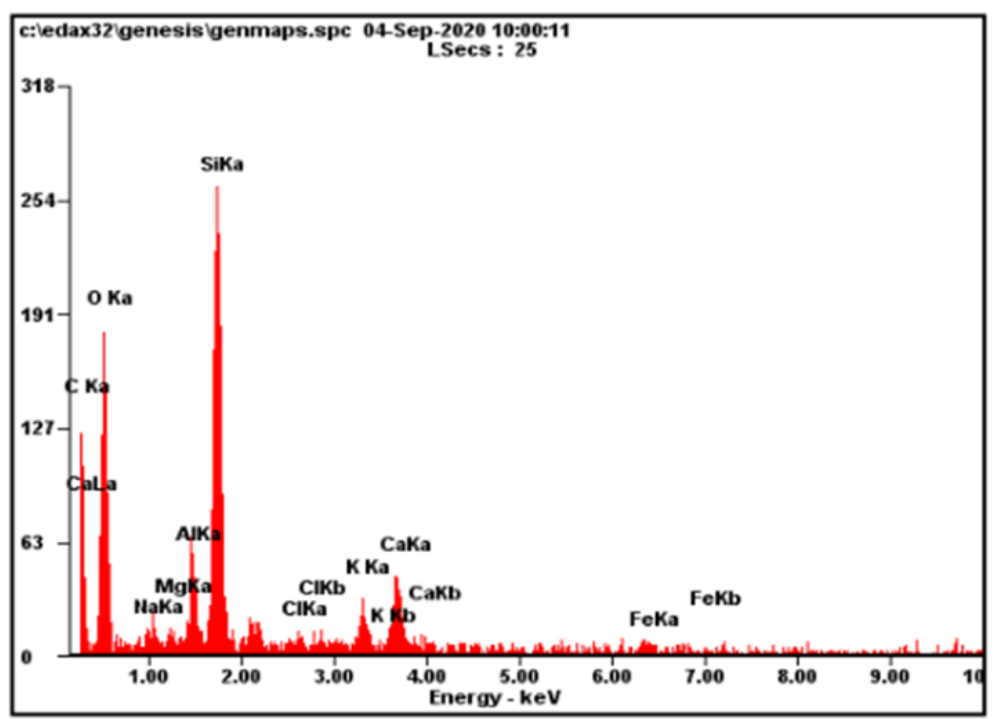

Fig 3. X-ray diffraction patterns on mineral sand samples

From the diffraction pattern above, it is clear that the dominant mineral phases are $\mathrm{Si}, \mathrm{Ca}$, and $\mathrm{K}$. The presence of these elements characterizes that the mineral sand from Samadua District is dominated by silica elements.

\section{B. SEM-EDX}

Based on the SEM-EDX test results on mineral sand samples as shown in Figure 4, the surface morphology is dominated by white. This shows that the color of the element silica is very strong and has a high atomic number.

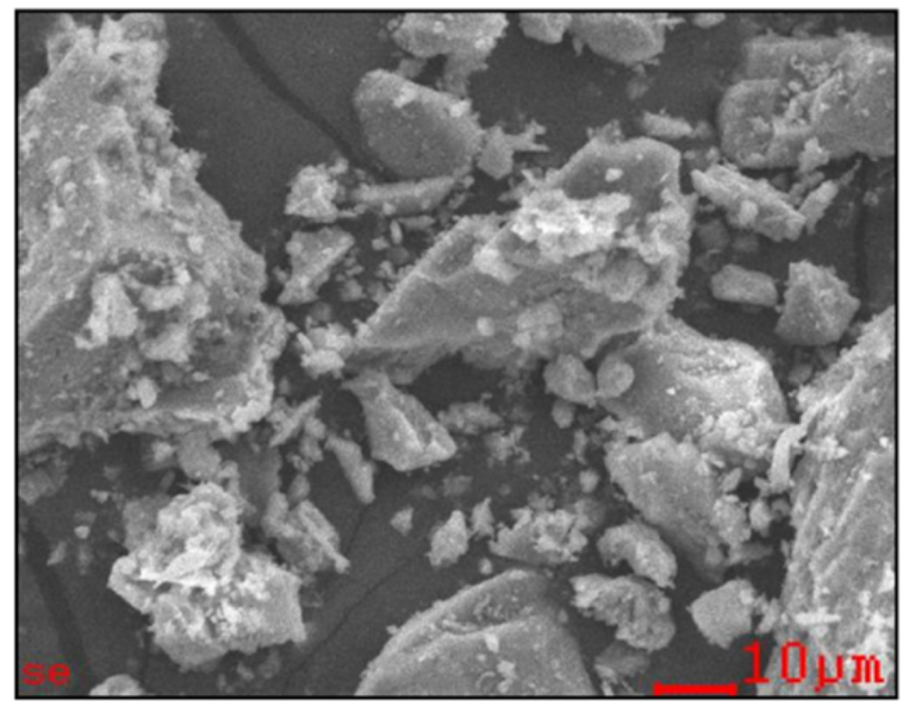

Fig 4. Surface morphological structure of mineral sand samples 


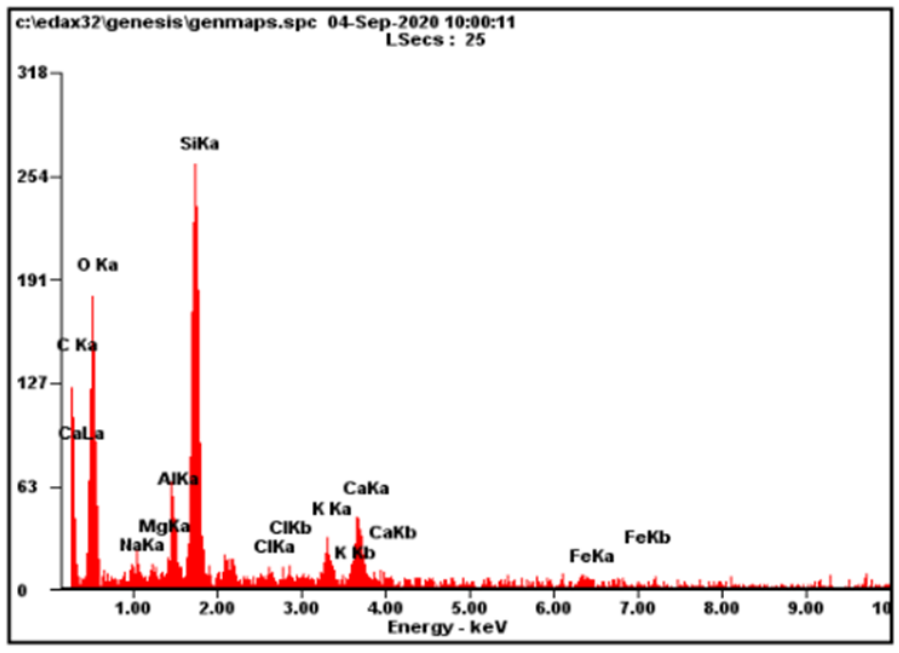

Fig 5. X-ray diffraction patterns on mineral sand samples

The results of EDX analysis show that the composition of mineral sand constituents in Samadua District is Si elements as large as $17.62 \mathrm{wt} \%$, followed by Ca elements as large as $04.30 \mathrm{wt} \%$, and $\mathrm{K}$ elements as rough as $02.42 \mathrm{wt} \%$.

\section{Conclusion}

The results of the analysis based on the X-Ray Diffraction and SEM-EDX tests, then the mineral sand obtained from Samadua District, South Aceh Regency is dominated by elements, namely Si, $\mathrm{Ca}$, and $\mathrm{K}$. and it is necessary to carry out further research with different methods.

\section{Acknowledgment}

Thanks to Direktorat Jenderal Pengutan Riset and Pengabdian Masyarakat who have funded this research through the scheme PDP implementation of the year 2020. Then to the Advanced Mineral and Material Laboratory, Faculty and Natural Sciences University of Malang for the opportunity to conduct sample testing, and LPPM Politeknik Aceh Selatan.

\section{References}

[1] B. S. Zulfikar, Iwan Aswan H., Corry Karangan, "INVENTARISASI DAN PENYELIDIKAN MINERAL NON LOGAM KABUPATEN ACEH SELATAN , PROVINSI NANGGROE ACEH DARUSSALAM," in Inventarisasi Dan Penyelidikan Mineral Non Logam Kabupaten Aceh Selatan, Provinsi Nangroe Aceh Darussalam, 2006.

[2] Sumarno, P. Novarita, M. Januarty, and Y. Yuniarti, "Pemurnian Pasir Silika dengan Metode Leaching Asam dan Bantuan Sonikasi," Semin. Nas. Tek. Kim. Kejuangan, no. 2001, pp. 1-8, 2015.

[3] I. Ukhtiyani and D. Darwis, "Purifikasi dan Karakterisasi Silika ( $\mathrm{SiO} 2$ ) Berbasis Pasir Kuarsa dari Desa Pasir Putih Kecamatan Pamona Selatan Kabupaten Poso Purification and characterization of quartz sand from Pasir Putih village, South Pamona sub-district of Poso," vol. 6, no. 3, pp. 270-275, 2017.

[4] B. Bin, D. Iman, and A. Rikardo, "Minerals Identification and Analysis of Granite Rocks in South Aceh District Using X-Ray Diffraction ( XRD )," vol. 4, no. 2, pp. 79-83, 2019.

[5] A. Rikardo and Z. Jalil, "The study of the Mineral Composition in the Granite Rocks in the Village of Lhok Pawoh, South Aceh District," vol. 5, no. 2, pp. 80-84, 2020. 